\title{
İkinci Sınıf Öğrencilerinin Müzik Yetenek Sınav Puanları ile Uygulamadan Elde Edilen Puanlar Arasındaki İlişkinin İncelenmesi
}

\section{Examining The Relationshıp Between The Talent Grades and The Final Grades of Second Class Students}

\begin{tabular}{|c|c|}
\hline & Meltem DÜZBASTILAR ${ }^{1}$ \\
\hline $\begin{array}{l}\text { Anahtar Kelimeler } \\
\text { Müzik eğitimi } \\
\text { Özel yetenek sınavı } \\
\text { Ezgi tekrarı } \\
\text { Ritim tekrarı }\end{array}$ & 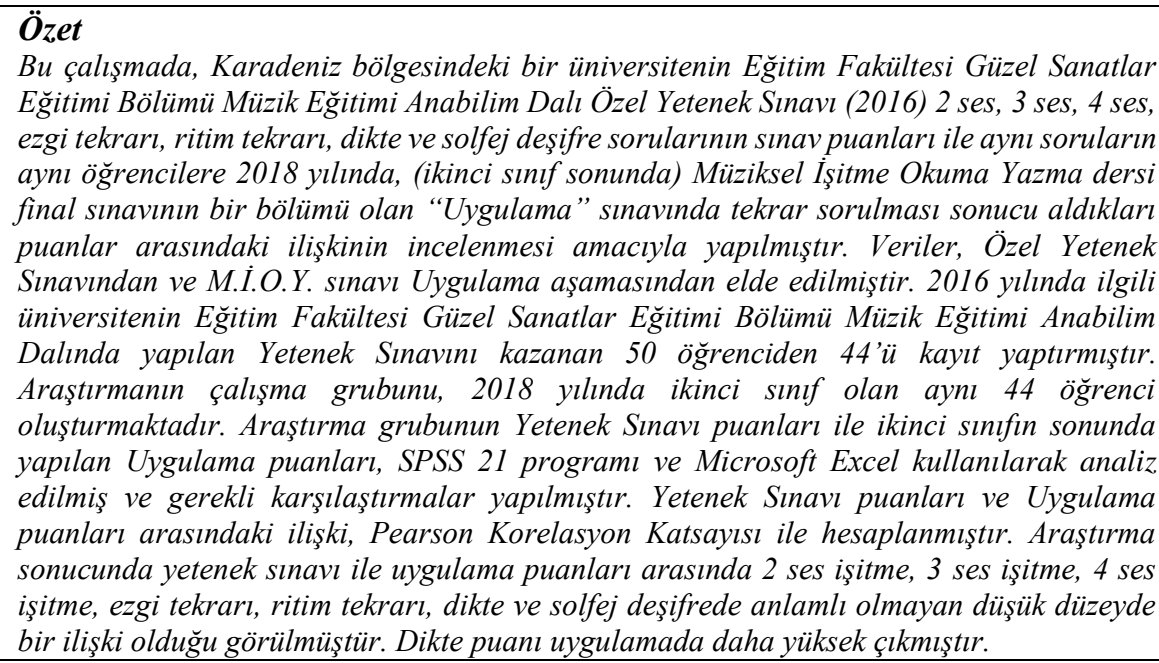 \\
\hline
\end{tabular}

\section{Abstract}

This study aims to examine the relationship between the talent exam grades (2016) of 2 voice hearing, 3 voice hearing, 4 voice hearing, melody repetition, rythym repetition, dictation and solfege and the implementation exam grades which is a part of final exam (2018) of second class undergraduate music education students of a University located in Blacksea reagion. The same questions were directed to the students both in talent exam and the final exam of Musical Hearing, Reading and Writing lesson at the end of the second semester of the second year, and the corelation among two exam scores are examined. The data is obtained from the talent exam and implementation exam. In 2016, 44 of 50 students who became successfull in talent exam of the related university Fine Arts Faculty Fine Arts Education Branch Music Education Department registered to the school. The study group consists of the same 44 students who were 2 nd class students in 2016. The talent exam grades and implementation exam grades which was held at the end of the second year are Key Word analysed and compared by using statistical analysis programs that frequently used in social Music education Talent exam Melody repetition Rythym repetition sciences. The relationship between the grades is measured with Pearson Correlation Coefficient.. As the result of the study, it's understood that there low relationship, which is not meaningful, between talent exam grades and implementation exam grades of two voice hearing, three voice hearing, four voice hearing, melody repetition, rythym repetition, dictation and solfege. Dictation grades are higher in implementation exam.

\begin{tabular}{ll}
\hline Atıf için: & Düzbastılar, M. (2019). İkinci sınıf öğrencilerinin müzik yetenek sınav puanları ile \\
For Citation & uygulamadan elde edilen puanlar arasındaki ilişkinin incelenmesi. Muğla Sitkı Koçman \\
& $\begin{array}{l}\text { Üniversitesi Eğitim Fakültesi [MSKU Journal of Education], 6(2), 88-97. } \\
\text { DOI:10.21666/muefd.574661 }\end{array}$ \\
\hline
\end{tabular}

Received: 10.06.2019 Accepted: 04.10.2019 $\quad$ Published: 01.11.2019

\footnotetext{
${ }^{1}$ Trabzon Üniversitesi Fatih Eğitim Fakültesi, meltemerol78@yahoo.com. ORCID 0000-0001-8346-596x
} 
Bireyleri ve toplumları biçimlendirme, yönlendirme, değiştirme, geliştirme ve yetkinleştirmede en etkili süreçlerin başında eğitim gelir. Müzik eğitimi ise, sanat eğitimi olarak güzel sanatlar eğitiminin en önemli dallarından birini oluşturur. Müzik eğitimi, bir müziksel davranış kazandırma, değiştirme ve geliştirme sürecidir (Uçan, 1997, s. 14). "Türkiye'de müzik eğitimi; genel, özengen ve mesleki olmak üzere üç gruba ayrılmaktadır" (Yener ve Apaydınl1, 2016, 225). "Mesleki müzik eğitimi, müzik alanının bütününü, bir kolunu ya da dalını, o bütün, kol ya da dal ile ilgili bir işi meslek olarak seçen, seçmek isteyen, seçme eğilimi gösteren, seçme olasılığı bulunan ya da öyle görünen, müziğe belli bir düzeyde yetenekli kişilere yönelik olup, dalın, işin ya da mesleğin gerektirdiği müziksel davranışları ve birikimi kazandırmayı amaçlar" (Uçan, 1997, s.32).

"Eğitim fakültelerinin güzel sanatlar eğitimi bölümü müzik öğretmenliği anabilim dalları, günümüzde örgün lisans eğitimi kapsamındaki başlıca mesleki müzik eğitimi kurumlarındandır. Ülkemizin müzik ögretmeni ihtiyac1, ağırlıklı olarak bu lisans programından mezun olan öğretmenlerle karşılanmaktadır" (Aksu ve Kurtuldu, 2016b, s. 15). "Ülkemizde özel yetenek gerektiren eğitim programları bulunan yükseköğretim kurumları, özel yetenek sınavlarında, adayların müzikal yeteneklerini ve becerilerini belirlemek amacı ile birkaç aşamada birbirine benzerlik gösteren sınavlar uygulamaktadırlar. Müziksel işitme-okuma-yazma, çalma ve söyleme alanındaki becerilerin değerlendirildiği sınavlarda anabilim dalları, kendi belirledikleri soru içeriklerine göre aşamalar belirleyip, bu aşamalarda adayı bireysel veya toplu olarak sinavlara almaktadırlar" (Ece ve Sazak, 2006 s.134). "Mesleki müzik eğitimi alacak öğrencilerin girdikleri özel yetenek sınavlarında ağırlıklı olarak test edilen davranışlar; müziksel işitme (ritim, ses ve ezgi tekrarı), müziksel okuma (solfej deşifresi), müziksel yazma (dikte yazma) ve müziksel icra (ses ve çalg1 performansı) şeklindedir" (Aksu ve Kurtuldu, 2016a. s. 193).

İlgili üniversitenin Eğitim Fakültesi Müzik Eğitimi Anabilim Dalında yapılan Özel Yetenek Sınavının içiriğini müziksel işitme, okuma, yazma; çalma ve söyleme basamakları oluşturmaktadır. Müzik Eğitimi Anabilim Dalında 2016 yılında yapılan özel yetenek sınavı iki aşamada yapılmıştır. "Birinci aşama; Müziksel İşitme - Yineleme ve Dikte sınavı, ikinci aşama; Solfej Okuma, Müziksel Söyleme ve Müziksel çalma sınavıdır" (Kılavuz, 2016). Kılavuzda (2016) belirtildiği gibi birinci aşamada dikte, dört tane iki ses, dört tane üç ses, iki tane dört ses, ikişer motiften oluşan tonal ve makamsal iki ezgi ve ikişer motiften oluşan iki ritim cümlesi bulunmaktadır. Müziksel İşitme - Yineleme ve Dikte sınavı Tablo 1'de verildiği şekilde hesaplanmaktadır.

Tablo 1. Birinci Aşama puanları

\begin{tabular}{ccccccc}
\hline $\begin{array}{c}\text { Dikte } \\
\text { Puanı }\end{array}$ & $\begin{array}{c}\text { İki Ses } \\
\text { İşitme }\end{array}$ & $\begin{array}{c}\text { Üç Ses } \\
\text { İşitme }\end{array}$ & $\begin{array}{c}\text { Dört Ses } \\
\text { İşitme }\end{array}$ & Ritim İşitme & Ezgi İşitme & $\begin{array}{c}\text { Toplam } \\
\text { Puan }\end{array}$ \\
\hline 30 & $4 \times 2=8$ & $4 \times 3=12$ & $2 \times 5=10$ & $8 \times 2=16$ & $8 \times 3=24$ & 100 \\
\hline
\end{tabular}

Birinci aşama sınavında, toplam kontenjan sayısı 150'dir. Yapılan eleme sonunda, programa alınmak üzere ilan edilen öğrenci kontenjanının (50) iki katı kadar aday (100), puan sıralamasına göre İkinci Aşama Sınavı'na alınmaktadır. İkinci aşamaya girmeye hak kazanan 100 adayın; "Solfej Okuma", "Müziksel Söyleme" ve "Müziksel Çalma" becerileri ölçülür. Solfej Okuma sınavında, "adayın temel nota ve ritim bilgisine dayalı doğru ve temiz solfej okuma becerisi ölçülmektedir". "Sınavda adaya verilecek olan solfej parçası aday tarafından okunmaktadır". "Sınavda adayın kendisine verilen solfeji okuması esnasında "notaları, ses aralıklarını, ses yüksekliklerini ve ritim kalıplarını" okuma derecesindeki doğruluk 100 üzerinden değerlendirilerek puanlanmaktadır" (Kılavuz, 2016). Daha sonra yapılan Müziksel Söyleme ve müziksel Çalma sınavları da 100 üzerinden değerlendirilmektedir. Konu ile ilgili olarak ulaşılan literatür incelendiğinde, Türkiye'de müzik eğitimi yetenek sınavı sorularının iki sene sonra aynı öğrencilere (bölümü kazanan) uygulanması ile ilgili başka bir çalışmaya rastlanmamıştır. Yetenek sınavı ile ilgili yapılan çalışmalar genellikle GSL ve Diğer lise mezunlarının karşılaştırılması; sınav puanları ile mezuniyet notu, akademik başarı, bazı lise ya da üniversite derslerinin karşılaştırılması şeklindedir. $\mathrm{Bu}$ çalışmaların bir kısmına Tartışma bölümünde değinilmiştir. 


\section{Araştırmanın Amacı}

Bu çalışma, Karadeniz bölgesindeki bir üniversitenin Müzik Eğitimi Anabilim Dalı 2016-2017 EğitimÖğretim yılı Özel Yetenek Sınavına ait 2 ses işitme, 3 ses işitme, 4 ses işitme, ezgi tekrarı, ritim tekrarı, dikte ve solfej deşifre sorularının sınav puanları ile aynı soruların Yetenek Sınavında başarılı olup ilgili bölümde öğrenim görmekte olan 2016 girişli Müzik Öğretmenliği öğrencilerine ikinci sınıf sonunda (2018) Müziksel İşitme Okuma Yazma dersi final sınavının bir bölümü olan Uygulama aşamasında tekrar sorulması sonucu aldıkları puanlar arasındaki ilişkinin incelenmesi amacıyla yapılmıştır.

Bu bağlamda, çalışmanın alt problemleri aşağıdaki gibidir:

1. Alt Problem: Özel Yetenek Sınavı ile ikinci sınıf sonunda aynı soruların aynı öğrencilere sorulmasıyla yapılan M.İ.O.Y. sınavı Uygulama aşaması "iki ses işitme, üç ses işitme, dört ses işitme" puanları arasındaki ilişki nedir?

2. Alt Problem: Özel Yetenek Sınavı ile M.İ.O.Y. sınavı Uygulama aşaması "Ezgi Tekrarı" puanları arasındaki ilişki nedir?

3. Alt Problem: Özel Yetenek Sınavı ile M.İ.O.Y. sınavı Uygulama aşaması "Ritim Tekrarı" puanları arasındaki ilişki nedir?

4. Alt Problem: Özel Yetenek Sınavı ile M.İ.O.Y. sınavı Uygulama aşaması "Dikte" puanları arasındaki ilişki nedir?

5. Alt Problem: Özel Yetenek Sınavı ile M.İ.O.Y. sınavı Uygulama aşaması "Deşifre (solfej)" puanları arasındaki ilişki nedir?

\section{Araştırmanın Önemi}

Çalışma, ikinci sınıfı bitiren öğrencilere, üniversiteye giriş yetenek sınavında kendilerine sorulan soruların aynısının sorulması sonucu, öğrencilerin iki yıllık gelişimleri ve değişimlerini ölçmesi bakımından önemlidir. Ayrıca, daha önce aynı şekilde uygulama yapılan bir çalışmaya rastlanılmamış olması bakımından da önemli olduğu düşünülmektedir.

Müziksel İşitme Okuma ve Yazma dersinin müzik eğitimi sürecindeki yeri ve önemi düşünüldügünde; iki sene Müziksel İşitme Okuma ve Yazma dersi almış olan öğrencilerin uygulama puanlarındaki düşüş ya da artışın, öğrencinin derse ilgisi, akademik başarısı, dersin içeriği ve işlenişi gibi birçok faktörü de akla getirmesi bakımından da ayrıca önemli olduğu düşünülmektedir.

\section{Varsayımlar}

$\mathrm{Bu}$ çalışma aşağıdaki varsayımlardan yola çıkılarak yapılmıştır:

1. Araştırmada kullanılan yetenek sınavı ve uygulama puanların geçerli ve güvenilir yöntemler kullanılarak elde edildikleri varsayılmıştır.

2. Araştırmada kullanılan yöntemlerin ve analiz tekniklerinin doğru olduğu varsayılmıştır.

\section{Sinırlılıklar}

1. Araştırma ilgili üniversitenin Müzik Eğitimi Anabilim Dalı ikinci sınıf öğrencilerinin yetenek sınavının (2016) birinci aşamasında yer alan 2 ses işitme, 3 ses işitme ve 4 ses işitme; ezgi tekrarı, ritim tekrarı, dikte ve deşifre (solfej) sorularının sınav puanlarının analizleri ile sinirlidir.

2. Araştırma, 2016 yılında özel yetenek sınavını kazanarak kayıt yaptıran 44 öğrenci ve 2018 yılında ikinci sınıf seviyesindeki aynı öğrenciler ile sınırlıdır. 


\section{Yöntem}

\section{Araştırma Modeli}

$\mathrm{Bu}$ araştırma, ilişkisel tarama modelinin kullanıldığı betimsel bir çalışmadır. Araştırmada, İlişkisel Araştırmalar'ın bir türü olan "Korelasyonel Araştırmalar" modeli kullanılmıştır. Korelasyonel Araştırmalar, iki veya daha fazla değişken arasındaki ilişkiyi betimlemek amacıyla, herhangi bir şekilde bu değişkenlere müdahale edilmeden yürütülen araştırmalardır (Karakaya, 2014, s.68; Büyüköztürk, Kılıç Çakmak, Karadeniz ve Demirel, 2016, s.185).

\section{Araştırma Grubu}

Araştırmanın çalışma grubunu, 2018 yılında ilgili üniversitenin Eğitim Fakültesi Güzel Sanatlar Eğitimi Bölümü Müzik Eğitimi Anabilim Dalında ikinci sınıfta okumakta olan 44 öğrenci oluşturmaktadır.

\section{Verilerin Toplanması}

Araştırmanın verileri Karadeniz bölgesinde bir üniversitenin E Müzik Eğitimi Anabilim Dalı yetenek sınavı soruları ve puanları, dekanlığın onayı ile Üniversite isminin belirtilmemesi koşuluyla elde edilmiştir. Bu nedenle araştırmada Üniversite ve Fakülte ismi belirtilmemiştir. Uygulama puanları ise, girdikleri yetenek sınavındaki soruların aynısının ikinci sınıfın sonunda MiOY final sınavinın bir bölümü olan Uygulama aşamasında tekrar sorulması sonucu aldıkları puanların hesaplanması ile elde edilmiştir.

\section{Verilerin Analizi}

Çalışma grubunun yetenek sınavı puanları ile ikinci sınıfın sonunda yapılan uygulama puanları, SPSS 21 programı ve Microsoft Excel kullanılarak analiz edilmiş ve gerekli karşılaştırmalar yapılmıştır.

Bulgular bölümünde Yetenek Sınavı puanları ve Uygulama puanları arasındaki ilişki, Pearson Korelasyon Katsayısı ile hesaplanmıştır. Pearson korelasyon katsayısı+1.00 ile -1.00 arasında değişen değerler alabilir. Değişkenlerin ikisi de aynı yönde değişme gösterirse, aralarındaki ilişki pozitiftir (+); değişkenlerden biri bir yönde değişirken, öteki ters yönde değişirse, bu durumda ilişki negatiftir (-). Değişkenler arasında ne pozitif ne de negatif yönde birlikte bir değişim yoksa, bu durumda korelasyon katsayısı sıfırdır (Arıcı, 2005, s.93). "Katsayı, 0.30-0.70 arasında kalıyor ise, iki değişken arasında orta düzeyde bir ilişkinin olduğu söylenebilir. Bu değer 0.70 'den büyük ise yüksek ve 0.30 'dan küçük ise düşük düzeyde bir ilişkiyi gösterdiği ifade edilebilir” (Köklü vd. 2006, s. 94).

Yapılan korelasyon ölçümlerinden önce normallik testi yapılmıştır. Normallik testi sonucunda elde edilen basıklık çarpıklık analizi sonuçları Tablo 2'de görülmektedir.

Yapılan normallik testi sonucunda, basıklık katsayılarının -1,629 ile 1,478 arasında; çarpıklık katsayılarının ise -,777 ile 1,906 arasında olduğu görülmektedir.

Basıklık çarpıklık katsayılarının sıfır olduğu durumlarda, dağılım standart normal bir dağılımdır; katsayıların sıfırdan uzaklaştığı durumlarda ise standart normal dağılımdan uzaklaşmaktadır denilebilir. (Köklü ve Büyüköztürk, 2000, s.68; Baykul, 1999, s.134; Altunışık vd., 2005, s.156). Analizlerde puanların, normal puanlara göre aşırı bir sapma durumunun olmamasına dikkat edilir. +1 -1 içerisinde kalan puanların, normal dağılıma göre aşırı bir sapma göstermediği söylenebilir (Köklü vd. 2006, s.63; Keskin ve Çiçek, 2005, s.54). Albayrak (2005), basıklık değeri için, +3 ile -3 arasında da karşılaşılabileceğini söylemiş̧ir.

$\mathrm{Bu}$ bilgilere dayanarak araştırma verilerinin normal dağılım gösterdiği söylenebilir. 
Tablo 2. Basıklık Çarpıklık Katsayıları

\begin{tabular}{|c|c|c|c|c|}
\hline \multirow{2}{*}{ Faktörler } & \multicolumn{2}{|l|}{ Basıklık } & \multicolumn{2}{|l|}{ Çarpıklık } \\
\hline & Ölçüm & SS & Ölçüm & SS \\
\hline Yetenek Sınavı 2 ses issitme & $-1,629$ & ,337 & 1,418 & 662 \\
\hline Yetenek Sınavı 3 ses isitme & $-1,283$ & 337 & 1,883 & 662 \\
\hline Yetenek Sınavı 4 ses işitme &,- 493 & 337 &,- 777 & 662 \\
\hline Uygulama 2 ses işitme & $-1,393$ &, 357 &, 798 & ,702 \\
\hline Uygulama 3 ses işitme &,- 189 &, 357 &,- 064 & ,702 \\
\hline Uygulama 4 ses işitme & , 196 &, 357 &,- 892 & ,702 \\
\hline Yetenek Sınavı Ezgi tekrarı &, 635 & 337 & ,969 & 662 \\
\hline Yetenek Sınavı Ritim tekrarı & ,067 & ,337 &,- 728 & ,662 \\
\hline Uygulama Ezgi tekrarı & 1,478 & 357 & 1,906 & ,702 \\
\hline Uygulama Ritim tekrarı &, 454 & 357 & ,929 &, 702 \\
\hline Yetenek Sınavı Dikte & $-1,218$ & 337 & 631 & ,662 \\
\hline Yetenek Sınavı Solfej Deşifre &,- 728 & 337 &,- 468 & ,662 \\
\hline Uygulama Dikte & $-1,565$ &, 357 & 1,483 & ,702 \\
\hline Uygulama Solfej Deşifre &,- 980 &, 357 &,- 611 & ,702 \\
\hline
\end{tabular}

\section{Bulgular ve Yorum}

Araştırmanın bulguları, yukarıda verilen alt problemlerin sırası ile sunulmuştur. Tablolarda, "Özel Yetenek Sınavı" puanları ve M.İ.O.Y. sınavı "Uygulama" aşaması puanları arasındaki ilişki, Pearson Korelasyon Katsayısı ile hesaplanmıştır. Yetenek Sınavı puanlarının ve ikinci sınıfın sonunda yapılan uygulama puanlarının ortalamaları alınmış ve ortalamaların farkı (\%) cinsinden verilmiştir. Bu sütunda yer alan verilerden, (-) değerde olanlar iki yılın sonunda puanlardaki düşüşü, $(+)$ olanlar ise iki yılın sonunda puanlardaki yükselişi göstermektedir.

\section{Birinci Alt Probleme İlişsin Bulgular ve Yorum}

Birinci alt problem; "Özel Yetenek Sınavı ile ikinci sınıf sonunda aynı soruların aynı öğrencilere sorulmasıyla yapılan M.İ.O.Y. sınavı Uygulama aşaması "İki Ses İşitme, Üç Ses İşitme, Dört Ses İşitme" puanları arasındaki ilişki nedir?" şeklindedir. Buna göre;

Tablo 2. "Özel Yetenek Sınavı" puanları ve M.İ.O.Y. sınavı "Uygulama” aşaması puanları (İki Ses İşitme, Üç Ses İşitme, Dört Ses İşitme) arasındaki ilişsi

Pearson Korelasyon

Katsayıları

Yetenek Sinavı ve Uygulama Puanları

Ortalamalarının Farkı (\%)

\begin{tabular}{ccc}
\hline İki Ses İșitme &,- 106 & $\%-0,06$ \\
\hline Üc Ses İșitme &, 098 & $\%-0,29$ \\
\hline Dört Ses İşitme &, 147 & $\%-0,17$ \\
\hline
\end{tabular}

Tablo 2'de, "Özel Yetenek Sinavı" ve M.İ.O.Y. sınavı "Uygulama" aşaması arasındaki İki Ses İşitmede negatif yönlü, anlamlı olmayan ve düşük düzeyde bir ilişki olduğu görülmektedir. Üç Ses İşitme ve Dört Ses İşitmede ise pozitif yönlü anlamlı olmayan ve düşük düzeyde bir ilişki olduğu görülmektedir. Yetenek sınavındaki İki Ses İşitme puanlarının ortalaması uygulama puanlarının ortalamasına göre \% 0,06 düşüş göstermiştir. İki yılın sonundaki uygulamada, Üç Ses İşitme ve Dört Ses İşitme puanlarının ortalamasında, İki Ses İşitmeye göre daha fazla düşüş olduğu görülmektedir. Puanlar arasında en fazla düşüş gösteren Üç Ses İşitmedir. Tablodaki değerlerden, öğrencilerin ikinci sınıf sonundaki Müziksel İşitme Okuma Yazma dersi final sınavının bir bölümü olan Uygulamada 
sorulan İki Ses İşitme, Üç Ses İşitme, Dört Ses İşitme sorularından aldıkları puanların, iki yıl önce aldıkları puanlara göre daha düşük olduğu anlaşılmaktadır.

\section{İkinci Alt Probleme İlişkin Bulgular ve Yorum}

İkinci alt problem; "Özel Yetenek Sınavı ile M.İ.O.Y. sınavı Uygulama aşaması "Ezgi Tekrarı" puanları arasındaki ilişki nedir?” şeklindedir. Buna göre;

Tablo 3. "Özel Yetenek Sınavı" puanları ve M.İ.O.Y. sınavı "Uygulama” aşaması puanları (Ezgi Tekrarı) arasındaki ilişki

\section{Pearson Korelasyon \\ Katsayıları}

Yetenek Sinavı ve Uygulama Puanları

Ortalamalarının Farkı (\%)

$\begin{array}{lll}\text { Ezgi Tekrarı } & , 127 & \%-0,07\end{array}$

Tablo 3'te Ezgi Tekrarı puanları yer almaktadır. "Özel Yetenek Sınavı" ve M.İ.O.Y. sinavı "Uygulama" aşaması arasındaki Ezgi Tekrarı puanları arasındaki korelasyon katsayısı ,127 olarak görülmektedir. Bu oran, puanlar arasında pozitif yönlü, anlamlı olmayan düşük düzeyde bir ilişki olduğu anlamına gelmektedir. Yetenek sınavındaki Ezgi Tekrarı puanlarının ortalaması ile uygulama puanlarının ortalaması arasında \%0,07 oranında bir düşüş görülmektedir. Yetenek sınavında alınan ezgi Tekrarı puanlarının ortalaması, uygulamada alınan puanlardan daha yüksek çıkmıştır. $\mathrm{Bu}$ sonuçtan, iki sene MIOY dersi aldıktan sonra Ezgi Tekrarı puanlarının düştüğü anlaşılmaktadır.

\section{Üçüncü Alt Probleme İlişkin Bulgular ve Yorum}

Üçüncü alt problem; "Özel Yetenek Sınavı ile M.İ.O.Y. sınavı Uygulama aşaması "Ritim Tekrarı" puanları arasındaki ilişki nedir?” şeklindedir. Buna göre;

Tablo 4. "Özel Yetenek Sınavı" puanları ve M.İ.O.Y. sınavı Uygulama aşaması puanları (Ritim Tekrarı) arasındaki ilişki

\begin{tabular}{ccc}
\hline & $\begin{array}{c}\text { Pearson Korelasyon } \\
\text { Katsayıları }\end{array}$ & $\begin{array}{c}\text { Yetenek Sinavı ve Uygulama Puanları } \\
\text { Ortalamalarının Farkı (\%) }\end{array}$ \\
\hline Ritim Tekrarı &, 128 & $\%-0,06$ \\
\hline
\end{tabular}

Ritim Tekrarında, "Özel Yetenek Sınavı" ve M.İ.O.Y. sınavı "Uygulama" aşaması puanları arasında ,128 oranında bir korelasyon görülmektedir. Bu oran, Yetenek ve Uygulama puanları arasında pozitif yönlü, anlamlı olmayan ve düşük düzeyde bir ilişki olduğu anlamına gelmektedir. Ritim Tekrarı puanlarının ortalaması iki yılın sonunda \%0,06 oranında düşmüştür. Ezgi Tekrarında olduğu gibi, Ritim Tekrarı puanlarının da iki sene önceki puanlara göre düştügü görülmektedir.

\section{Dördüncü Alt Probleme İlişkin Bulgular ve Yorum}

Dördüncü alt problem; "Özel Yetenek Sınavı ile M.İ.O.Y. sınavı Uygulama aşaması "Dikte" puanları arasındaki ilişki nedir?” şeklindedir. Buna göre;

Tablo 5. "Özel Yetenek Sınavı" puanları ve M.İ.O.Y. sınavı "Uygulama" aşaması puanları (Dikte Tekrarı) arasındaki ilişki

\begin{tabular}{ccc}
\hline & $\begin{array}{c}\text { Pearson Korelasyon } \\
\text { Katsayıları }\end{array}$ & $\begin{array}{c}\text { Yetenek Sinavı ve Uygulama Puanları } \\
\text { Ortalamalarının Farkı (\%) }\end{array}$ \\
\hline Dikte &,- 222 & $\%(+) 0,08$ \\
\hline
\end{tabular}


Dikte aşamasında, “Özel Yetenek Sınavı" ve M.İ.O.Y. sınavı "Uygulama” aşaması puanları arasındaki korelasyon katsayıs1 -,222'dır. Bu oran Yetenek Sinav1 ve Uygulamadaki Dikte puanları arasında negatif yönde, anlamlı olmayan ve düşük düzeyde bir ilişki olduğu anlamına gelmektedir. Diğer sonuçlarda karşılaşılan düşüşten farklı olarak Dikte puanlarının ortalaması \%0,08 oranında yükselmiştir.

\section{Beşinci Alt Probleme İlişkin Bulgular ve Yorum}

Beşinci alt problem; "Yetenek Sınavı ile M.İ.O.Y. sınavı Uygulama aşaması "Solfej Deşifre" puanları arasındaki ilişki nedir?" şeklindedir. Buna göre;

Tablo 6. "Özel Yetenek Sınavı" puanları ve M.İ.O.Y. sınav1 "Uygulama” aşaması puanları (Solfej Deşifre) arasındaki ilişki

\section{Pearson Korelasyon Yetenek Sinavı ve Uygulama Puanları Katsayıları Ortalamalarının Farkı (\%)}

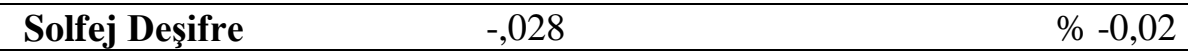

Solfej Deşifre aşamasında, “Özel Yetenek Sınavı” ve M.İ.O.Y. sınavı "Uygulama” aşaması puanları arasındaki korelasyon katsayısı -,028 olarak görülmektedir. Bu oran, puanlar arasında negatif yönlü, anlamlı olmayan ve çok düşük düzeyde bir ilişki olduğu anlamına gelmektedir. İki yılın sonunda yapılan uygulama puanlarının ortalamalarının \% 0,02 oranında düştüğü görülmektedir.

\section{Tartışma, Sonuç ve Öneriler}

Özgür ve Aydoğan'ın (2015) belirttiği gibi, Müziksel İşitme Okuma Yazma öğretimi; yapısıyla mesleki müzik eğitiminin en temel alanı durumundadır. Müziksel işitme-algılama, müziksel yazma, müziksel okuma, müziksel belleme, müziksel yaratma, müziksel düşünme (tasarlama), müziksel değerlendirme ve müziksel çözümlemeye ilişkin davranış değişikliklerini hedeflediğinden dolayı MIOY dersi aldıktan sonra öğrencilerin bu alanlara yönelik davranışlarında olumlu yönde değişiklik beklenmektedir. $\mathrm{Bu}$ beklentinin aksine, sadece dikte puanlarındaki yükseliş, derslerde dikte çalışmalarına daha fazla ağırlık verilmesinden olabilir. Hem Yetenek Sınavı puanları hem de M.İ.O.Y. sınavı Uygulama aşaması puanları, sınav sırasında alınmış olmasına rağmen, uygulama puanlarının çoğunda düşüş olmuştur. İki sene MIOY dersi aldıktan sonra puanların düşmesinin nedeni; yetenek sınavının "Üniversite Giriş Sınavı" olması dolayısıyla, öğrencilerin hazır bulunuşluk düzeylerinin daha yüksek olmasından kaynaklanabilir. Ayrıca, yetenek sınavında iki ses işitme, üç ses işitme, dört ses işitme, ezgi tekrarı, ritim tekrarı ve solfej deşifre aşamalarında puanların daha yüksek olması, ögrencilerin sınava hazırlanma aşamasında, sınavda çıkabilecek tür sorulara yoğunlaşmaları ve aynı tarzdaki çalışmaları sürekli tekrar etmelerinden kaynaklanabilir. Konu ile ilgili olarak ulaşılan literatürde, Türkiye'de müzik eğitimi yetenek sınavı sorularının iki sene sonra aynı öğrencilere (bölümü kazanan) uygulanması ile ilgili başka bir çalışmaya rastlanmamıştır.

Yapılan benzer çalışmalar, genellikle GSL ve Diğer lise mezunlarının karşılaştırılması; sınav puanları ile mezuniyet notu, akademik başarı, bazı lise ya da üniversite derslerinin karşılaştırılması şeklindedir. Demirbatır ve arkadaşları tarafından 2015 yılında "A comparative examination of the 2013 Musical Aptitude Test scores of music education students and their 1st academic year GPAs" başlıklı bir çalışma yapılmıştır. Müzik Yetenek Sınavı sonuçlarının uygunluğunu belirlemeyi amaçlayan çalışmalarında, 2013 yılının Müzik Yetenek Testi sonuçları ile birinci sınıf akademik başarılarını karşılaştırmışlardır. Araştırmada, Müziksel İşitme Okuma ve Yazmanın akademik başarısı ile Müzik Yetenek Testi birinci aşama arasında pozitif yönde ilişki olduğu sonucu ortaya çıkmıştır. Aynı zamanda, Müziksel İşitme Okuma ve Yazmanın akademik başarısı ile Müziksel İşitme Testi arasında, Çalgı eğitimi akademik başarısı ile çalgı sınavı arasında ve Ses Eğitimi akademik başarısı ile söyleme sınavı arasında da pozitif yönde ilişki olduğu sonucu ortaya çıkmıştır. 
Şengül 2001 yılında, "Müzik eğitimi bölümlerinin giriş-yetenek sınavlarına başvuran adayların müziksel işitme-yineleme sınavındaki soru tiplerine göre başarı durumlarının belirlenmesi" başlıklı yüksek lisans çalışmasında, birinci aşama sınavındaki müziksel okuma - yineleme performanslarını değerlendirmiştir. Araştırmada, en başarılı boyutun "tek ses işitme" olduğunu; çok sesli işitmede, ses sayısındaki artışla birlikte başarı başarı oranında azalma olduğu sonucuna ulaşmıştır. Ritim işitmedeki başarı düzeylerinin ezgi işitmeye göre daha yüksek olduğu belirlenmiştir.

Demirbatır 1993 y1lında, "Uludağ Üniversitesi Eğitim Fakültesi Müzik Eğitimi Bölümü Öğrencilerinin Bölüme Giristeki Müziksel Başarılarıyla Birinci Y1l Sonundaki Müziksel Başarılarının Karşılaştırılarak İncelenmesi’'başlıklı yüksek lisans tezinde; müziksel işitme yetenek sınavı ile müziksel işitme ve okuma dersi birinci yarıyıl başarıları arasında pozitif yönlü anlamlı ilişkiler olduğu, ikinci yarıyıl başarıları ansındaki ilişki düzeyinin ise yetersiz kaldığı görülmüştür.

Kurtuldu ve Aksu (2017) yaptıkları araştırmada, "Müzik Öğretmeni Adaylarının Yetenek Sınavı Puanları ile Lisans Akademik Başarı Puanları Arasındaki İlişki”yi incelmişlerdir. Çalışmadan elde edilen sonuçlardan biri, çalışma grubunu oluşturan müzik öğretmeni adaylarının özel yetenek sınavından aldıkları ham puanlarla (YHP) Lisans Programı Dönem Sonu AGNO (Ağırlıklı Genel Not Ortalamaları) arasında hiç ilişki olmadığ ya da çok düşük düzeyde bir ilişki olduğudur. Çalışmadan elde edilen bir diğer bulgu ise; çalışma grubundaki öğrencilerin özel yetenek sınav puanları ile lisans programı akademik puanları arasında 'Sınıf Düzeyi' değişkenine YHP açısından bakıldı̆̆ında 2. Sınıflarda anlamlı bir farklılığa rastlanmamıştır.

Sonuçlar;

1. "Özel Yetenek Sınavi” ve M.İ.O.Y. sınavı "Uygulama" aşaması arasındaki İki Ses İșitmede negatif yönlü, anlamlı olmayan ve düşük düzeyde bir ilişki olduğu görülmektedir. Üç Ses İşitme ve Dört Ses İşitmede ise pozitif yönlü anlamlı olmayan ve düşük düzeyde bir ilişki olduğu görülmektedir. Yetenek sınavındaki İki Ses İşitme puanlarının ortalaması uygulama puanlarının ortalamasına göre \% 0,06 düşüş göstermiştir. Elde edilen sonuçlardan, Müziksel İşitme Okuma Yazma dersi final sınavının bir bölümü olan "Uygulamada" sorulan İki Ses İşitme, Üç Ses İşitme, Dört Ses İşitme sorularından aldıkları puanların, iki yıl önce aldıkları puanlara göre daha düşük olduğu anlaşılmaktadır.

2. Ezgi Tekrarı puanlarının "Özel Yetenek Sınavı" ve M.İ.O.Y. sınavı "Uygulama" aşaması arasındaki korelasyon katsayısı ,127 olarak görülmektedir. Bu oran, puanlar arasında pozitif yönlü, anlamlı olmayan düşük düzeyde bir ilişki olduğu anlamına gelmektedir. Yetenek sınavındaki Ezgi Tekrarı puanlarının ortalaması ile uygulama puanlarının ortalaması arasında \%0,07 oranında bir düşüş görülmektedir. Bu sonuçtan, iki sene MIOYY dersi alınmasına rağmen Ezgi Tekrarı puanlarının düştüğü anlaşılmaktadır.

3. Ritim Tekrarında, "Özel Yetenek Sınavı" ve M.İ.O.Y. sınavı "Uygulama" aşaması puanları arasında ,128 oranında bir korelasyon görülmektedir. Bu oran, Yetenek ve Uygulama puanları arasında pozitif yönlü, anlamlı olmayan ve düşük düzeyde bir ilişki olduğu anlamına gelmektedir. Ritim Tekrarı puanlarının ortalaması iki yılın sonunda \%0,06 oranında düşmüştür.

4. Dikte aşamasında, "Özel Yetenek Sınavı" ve M.İ.O.Y. sınavı "Uygulama” aşaması puanları arasındaki korelasyon katsayıs1 -,222'dır. Bu oran Yetenek Sınavı ve Uygulamadaki Dikte puanları arasında negatif yönde, anlamlı olmayan ve düşük düzeyde bir ilişki olduğu anlamına gelmektedir. Diğer sonuçlarda karşılaşılan düşüşten farklı olarak Dikte puanlarının ortalaması $\% 0,08$ oranında yükselmiştir.

5. Solfej Deşifre aşamasında, "Özel Yetenek Sınavı" ve M.İ.O.Y. sınavı "Uygulama" aşaması puanları arasındaki korelasyon katsayıs1 -,028 olarak görülmektedir. Bu oran, puanlar arasında negatif yönlü, anlamlı olmayan ve çok düşük düzeyde bir ilişki olduğu anlamına gelmektedir. İki yılın sonunda yapılan uygulama puanlarının ortalamalarının \% 0,02 oranında düştüğü görülmektedir. 
Öneriler;

- İki Ses İşitme, Üç Ses İşitme, Dört Ses İşitme, Ezgi Tekrarı, Ritim Tekrarı ve Solfej Deşifrede karşılaşılan düşüşler göz önüne alındığında Müziksel İşitme Okuma Yazma derslerinde müziksel hafıza geliştirme çalışmalarına daha fazla yer verilebilir.

- Ezgisel hafizayı geliştirmek için öğrenciler farklı türde ve uzunluktaki ezberlemeye yönlendirilebilirler.

- Ritmik hafızalarını geliştirmeleri için ritim tekrarı çalışmalarının artırılabileceği gibi; öğrencilerin bireysel çalg1 eğitimi, bireysel ses eğitimi ve toplu icra derslerindeki eserleri ezberlemeleri faydalı olabilir.

- Solfej Deşifre becerilenin geliştirilebilmesi için Müziksel İşitme Okuma Yazma derslerinde bona ve solfej deşifre çalışmaları artırılabilir.

- Öğrenciler, okula kayıt yaptırdıktan sonra da ezgisel ve ritmik hafızanın geliştirilmesine devam edilmesi konusunda uyarılabilir ve yönlendirilebilirler.

- Benzer çalışmalar yetenek sınavı ile öğrenci alınan farklı okullarda, bölümlerde yapılabilir.

\section{Kaynakça}

Aksu, C. \& Kurtuldu, M. K. (2016a). GSL mezunu öğrencilerin lisans yetenek sınav puanlarının bazı lise derslerine göre karşılaştırılması. Akademik Sosyal Araştırmalar Dergisi, 4(36), 191-206.

Aksu, C. \& Kurtuldu, M. K. (2016b). GSL ve diğer lise mezunlarının lisans akademik başarılarının bazı derslere göre karşılaştırılması. The Journal of Academic Social Science Studies, 52, 1528.

Albayrak, A. S. (2005). Çok değiş̧kenli istatistik tekniklerinin varsayımları. Ş. Kalaycı (Ed.), Spss uygulamalı çok değişkenli istatistik teknikleri içinde, (s. 207-230). Ankara: Asil Yayın dağılım Ltd. Şti.

Alpan, O., \& Arpacık, R. (1990). İstatistik uygulamalar. Ankara: Veteriner fakültesi.

Arıc1, H. (2005). Istatistik yöntemler ve uygulamalar. Meteksan Anonim Şirketi. Ankara.

Altunışık, R.,Coşkun, R., \& Bayraktaroğlu, S. (2005). Sosyal Bilimlerde Araştırma Yöntemleri. Baskı: Avc1 Ofset.

Karakaya, İ. (2014). Bilimsel araştırma yöntemleri. A. Tanrı̈ğen (Ed.), Bilimsel araştırma yöntemleri içinde, (4. Bask1), (s. 57-83). Ankara: Anı Yayınc1lık.

Baykul, Y. (1999). Istatistik Metodlar ve Uygulamalar, Ankara: Anı Yayınc1lı.

Büyüköztürk, Ş., Kılıç Çakmak, E.; Akgün Ö.; Karadeniz, Ş. ve Demirel, F. (2016). Bilimsel Araştırma Yöntemleri, Ankara: Pegem Akademi.

Demirbatır, R. E., Çeliktaş, H., Engur, D. (2015). A comparative examination of the 2013 Musical Aptitude Test scores of music education students and their 1st academic year GPAs. Procedia - Social and Behavioral Sciences, 197, 815 - 820.

Demirbatır, R., E. (1993). Uludağ üniversitesi eğitim fakültesi müzik eğitimi bölümü öğrencilerinin bölüme girişteki müziksel başarılarıyla birinci yılsonundaki müziksel başarılarının karşılaştırılarak incelenmesi. Gazi Üniversitesi, Fen Bilimleri Enstitüsü. Ankara.

Ece, A. S. \& Sazak, N. (2006). Özel yetenek sınavlarında ÖSS puanı ile yetenek puanları (işitme alanı, ses alanı, çalg1 alanı) arasındaki ilişkilerin incelenmesi. Trakya Üniversitesi Sosyal Bilimler Dergisi, 8(1), 133-144.

Keskin, H. Ü., Çiçek, E. U. (2005). Tanımlayıcı İstatistikler. Ş. Kalaycı (Ed.), Spss uygulamalı çok değişkenli istatistik teknikleri içinde, (s. 51-58). Ankara: Asil Yayın dağılım Ltd.

Kılavuz. (2016). Ĕgitim fakültesi müzik öğretmenliği ve resim-iş öğretmenliği, güzel sanatlar fakültesi resim bölümü 2016 yılı özel yetenek sinavları kılavuzu. Temmuz, Trabzon.

Köklü N. \& Büyüköztürk, Ş. (2000). Sosyal bilimler için istatistiğe giriş, Ankara: Pegem A. Yayıncilik.

Köklü N., -Büyüköztürk, Ş., \& Bökeoğlu, Ö. Ç. (2006). Sosyal bilimler için istatistik, Ankara: Pegem A Yayınc1lik. 
K Kurtuldu, M. K. \& Aksu, C. (2017). Müzik öğretmeni adaylarının yetenek sınavı puanları ile lisans akademik başarı puanları arasındaki ilişki. Sanat Ĕ̈itimi Dergisi, 5(1), DOI: 10.7816/sed-0501-03.

Özgür, Ü. \& Aydoğan, S. (2015). Müziksel işitme okuma ĕgitimi ve kuram. Ankara: Arkadaş Yayınevi.

Şengül, C. (2001). Müzik eğitimi bölümlerinin giriş-yetenek sınavlarına başvuran adayların müziksel işitme-yineleme sınavındaki soru tiplerine göre başarı durumlarının belirlenmesi. (Yayımlanmamış yüksek lisans tezi). Gazi Üniversitesi Eğitim Bilimleri Enstitüsü Güzel Sanatlar Eğitimi Anabilim Dalı Müzik Eğitimi Bilim Dalı. Ankara.

Uçan, A. (1997). Müzik eğitimi temel kavramlar-ilkeler-yaklaşımlar. Müzik Ansiklopedisi Yayınları. Ankara.

Yener, S., \& Apaydınl1, K. (2016). Türkiye'de mesleki müzik eğitimi veren kurumların çeşitliliği ve mezunların istihdam sorunları. The Journal of Academic Social Science Studies, 42, 225-249. 